\title{
Multimodal Analysis of Kizuna, Oya Kara Ko E Dansu Advertisement
}

\author{
Mhd. Pujiono, Universitas Sumatera Utara
}

\begin{abstract}
Language as a communication tool is an integral part of human being. Verbal communication is daily communication delivered in spoken or written forms, while the nonverbal communication has somehow lost its significance even though these two ways of communication apparently creates a valuable unification when both of them are utilized altogether. Our comprehension will be apparently limited if we ignore the nonverbal communication that uses gestures, object, and color as the media. Therefore, this paper highlights the combination of verbal and nonverbal communication in an advertisement by discussing the multimodality of Kizuna, Oyakarako $e$ Dansu advertisement. The advertisement promotes Pokarisuetto, a popular drink produced in Japan. Pokarisuetto is a healthy drink which is very popular. Either in printed or electronic advertisement, the complexity of the meaning is very obvious. This is due to the message delivery process that is not merely language oriented but also visual and gesture oriented. In order to provide the overview of the complexity of the meaning, multimodal analysis is required. The multimodal analysis discussed in this paper uses the theory of functional systemic linguistic and the model of multimodality as proposed by Anstey and Bull (2000) and Kress and Van Leeuwen (2006). The result of the analysis shows that there is a semiotic multimodality system that covers the linguistic, visual, audio, gestural and spatial elements of Kizuna, Oyakarako e Dansu advertisement.
\end{abstract}

Keywords: advertisement analysis; Japanese language; multimodality; nonverbal communication.

\section{Introduction}

Electronic advertisement is one of the media that stipulates the complexity of meaning. The complexity of meaning is intended to show that the message is not only presented in verbal form but also in nonverbal form. Therefore, in order to comprehend the complexity of meaning, the multimodal analysis of advertisement is obviously needed.

In the text of advertisement, the name of the product, the idea, and the service which is beneficial for the consumers are attached. An advertisement has goals and one of the goals is to inform, remind, and persuade consumers to do something upon/toward the advertised product/service (Kotler \& Amstrong, 2009 and Matthiessen, 2010).

As one of the studies conducted within the scope of systemic functional linguistic that looks upon text as a functional unit language within social context (Halliday, 2004), multimodal analysis emphasizes on the important role of media in either verbal or nonverbal communication in terms of creating the meaning. Since language contains informative meaning, multimodal analysis is used to analyze all means of communication that incorporate interaction and integration of two or more semiotics or communication media to achieve the communicative function of text by O'Halloran and Smith (in Sinar, 2012).

The advertisement analyzed in this paper taken from popular energy drink advertisement, Pocari Sweat is entitled Kizuna, Oyakarako e Dansu which means a bound of mother's dance and the child. The duration of this advertisement starred by famous Japanese actress Ishii Anna is 29 seconds. The analysis is conducted to describe the multimodal elements found in the advertisement.

\section{Methodology}

This paper uses descriptive qualitative approach to analyze the data that is taken in the form of advertisement video of a famous energy drink called Pocari Sweat entitled Kizuna, Oyakarako e Dansu. The analysis of the data utilizes multimodal analysis. The multimodal analysis discussed in this paper uses the theory of functional systemic linguistic with the 
combination development stated by Anstey and Bull's (2010) theory and Kress and Van Leeuwen's (1996) multimodal theory.

Anstey and Bull (2010) in their multimodal analysis theory said that a text is considered as multimodal if the text is the amalgamation between two or more semiotic system. According to Anstey and Bull (2010), there are five multimodal semiotic systems in a text namely: 1) Linguistics system that consists of vocabulary, generic structure and grammar of oral and written language, 2) Visual system that is composed of color, vectors and viewpoint in still, and moving images, 3) Audio system that comprises volume, pitch and rhythm of music, and sound effects, 4) Gestural system that is made up of movement, speed and stillness in facial expression, and body language, and 5) Spatial system that comprises proximity, direction, position of layout and organization of objects in space.

Moreover, the analysis of multimodal composition related to the prevailing representational and interactive meaning of the images proposed by Kress and Leeuwen (in Sinar, 2012) is divided into three systems:

\section{a. Information value.}

The mold of participants' elements and the syntagmatic components that connects the image slides gives specific information values about what kind of elements contained in the images that can be seen from the right, left, above, below, or middle side. There are two information values, namely: Centered information value that puts the center element in the middle of the composition which consists of Triptych and the non-central element is placed in the right, left, above or below side and Circular information value that puts the non-central element in the above or below or sides of the center and other element is put between polarized position, which is no element in the middle of a composition.

\section{b. Salience}

The elements of participant, representation and interactive syntagmatic are made for attracting the viewer with different degrees of set of the background, foreground, relative size color contrast, sharpness and so on.

\section{c. Framing}

The presence or the absence of framing tool is placed into realization by the elements to create boundary line or framing line that relate each other by giving the sign that there are parts or non-parts in the framing.

\section{Results and discussion \\ 3.1 Linguistic Analysis} advertisement.

The following table is verbal text transcription of the Kizuna, Oyakarako e Dansu

Table 1: Verbal text transcription

\begin{tabular}{|l|l|}
\hline \multicolumn{1}{|c|}{ Transcription } & \multicolumn{1}{|c|}{ Meaning } \\
\hline Hassai, pokarisuetto to deatta & $\begin{array}{l}\text { The first time I know pocari sweat is when I } \\
\text { was 8 years old. }\end{array}$ \\
\hline Tooigatsu no hi & The previous day \\
\hline Happyokai no maeniase o nagashiteitta. & $\begin{array}{l}\text { Before I performed Ballett, I was always } \\
\text { sweating }\end{array}$ \\
\hline $\begin{array}{l}\text { Hahagakuretanomimonowaima made } \\
\text { onajidata }\end{array}$ & $\begin{array}{l}\text { The drink that my mother gave to me never } \\
\text { changes }\end{array}$ \\
\hline Imawatashi no musumegadansu o hajimeta & Now my daughter has started dancing \\
\hline Yume nimukauaseto & By our own sweat we can achieve our dream \\
\hline Sore wamusumeniuketsunareteiru & That's my legacy to my daughter \\
\hline Ano hi kara, zuttopokarisuetto & Since that day, till now Pocari Sweat \\
\hline
\end{tabular}


The variety of the spoken elements above is informal. This variety is intended to erase the gap or the distance between the message and the consumers. Besides, this language variety shows the modernity of this advertisement. Moreover, the emphasized meaning found in the spoken verbal variety of this advertisement is strengthened by the presence of the variety of the written element shown in the form of written text and the visual emblem.

The following are the visual text appears in the advertisement.

Table 2: Written text transcription

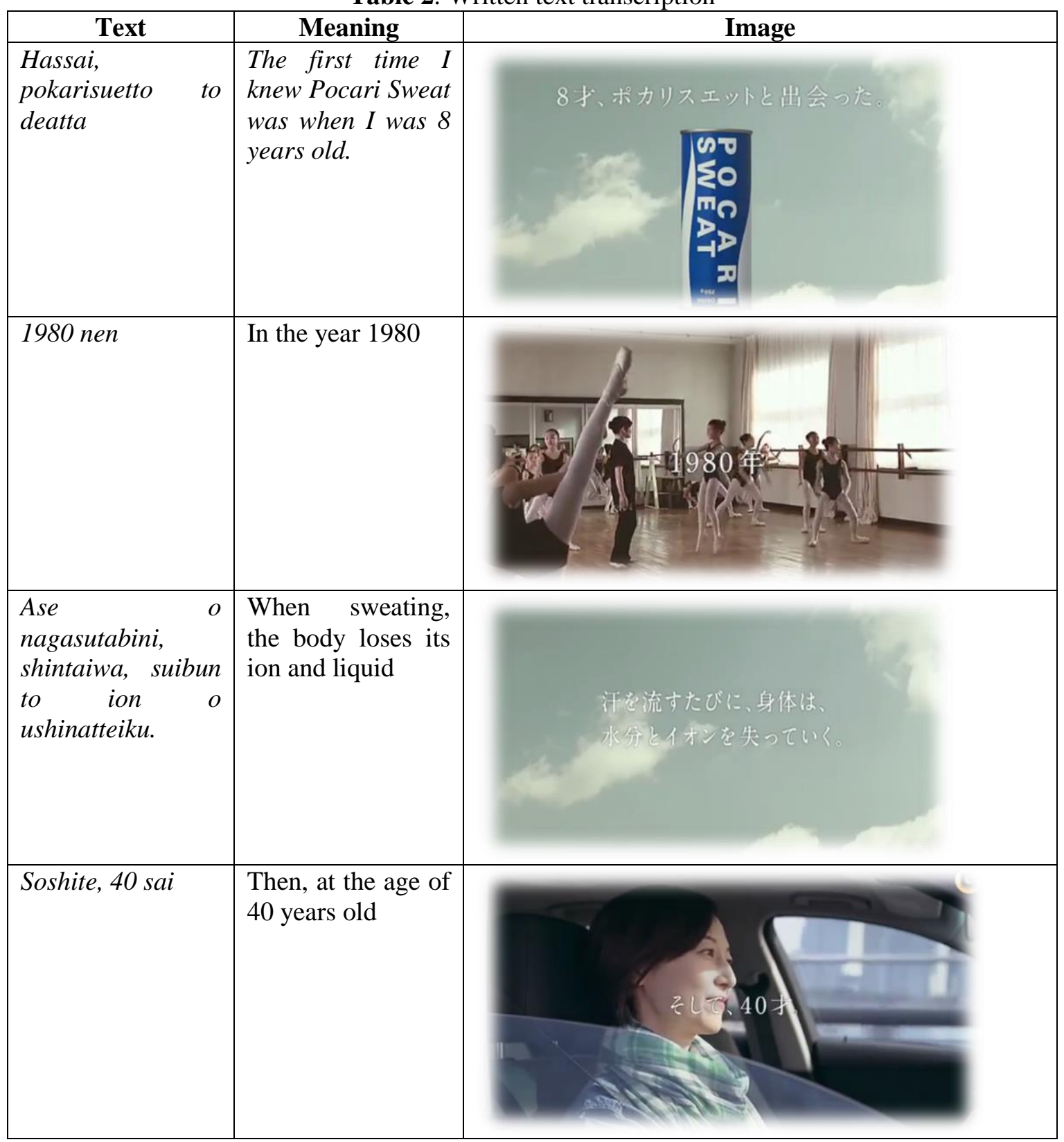


Table 2, cont.

\begin{tabular}{|l|l|l|l|}
\hline $\begin{array}{l}\text { Hitowa, ion to } \\
\text { ikiteiku } \\
\text { ion }\end{array}$ & $\begin{array}{l}\text { Human lives with } \\
\text { now hi karazutto }\end{array}$ & $\begin{array}{l}\text { Since that day till } \\
\text { now }\end{array}$ & \\
\hline
\end{tabular}

Figure 1: The product emblem of Pocari Sweat advertisement

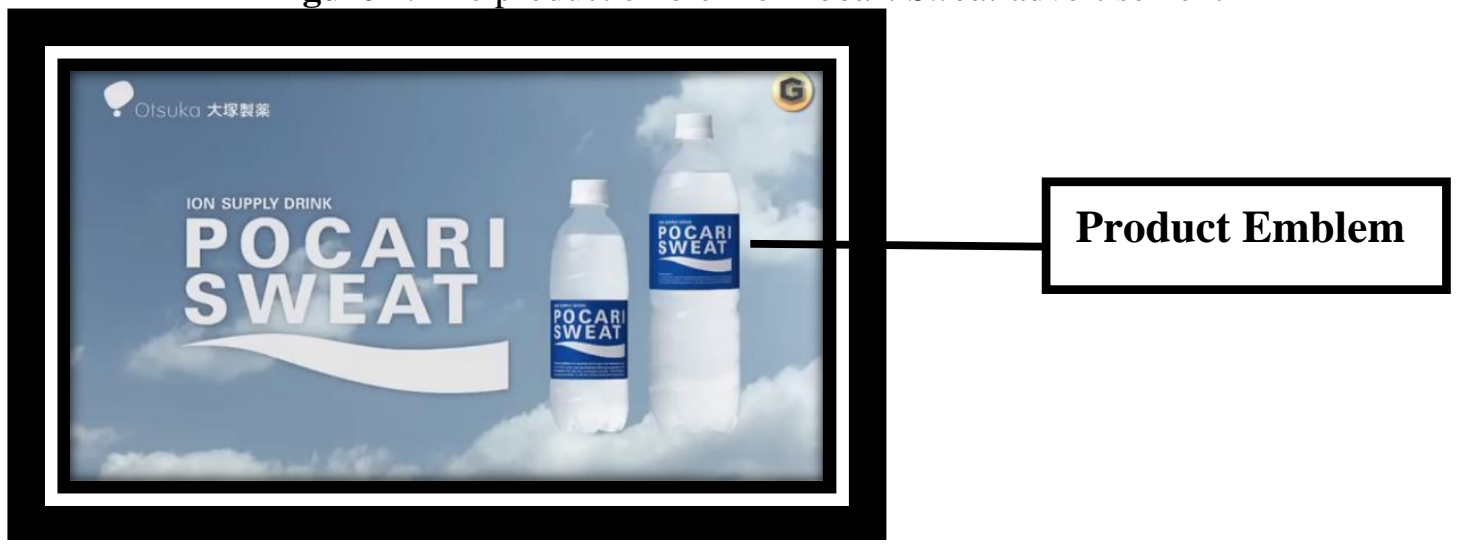

The message in Pocari Sweat advertisement is delivered through an announcement that is considered as the only one advertisement message, which is the most important interpersonal aspect amongst other messages within the text.

The process occurred in the announcement as the prime message of the advertisement is the behavioral process of ano hi karazuttopokarisuetto or 'since that day till now on, Pocari Sweat is the only one'. That behavioral process has an imperative mode. This kind of modus is to persuade the consumers to consume the advertised thinking product, which is Pocari Sweat.

\subsection{Visual Analysis}

The visual analysis of this advertisement puts three visual steps into realizations; 1) the visual of the advertisement actress stared by Ishii Anna, 2) the visual of the product, Pocari Sweat, and 3) the visual of the emblem. These three visuals run in 29 seconds. The realizations of these three visual elements are being described in the following pictures: 
Figure 2: The visualization in Pocari Sweat advertisement

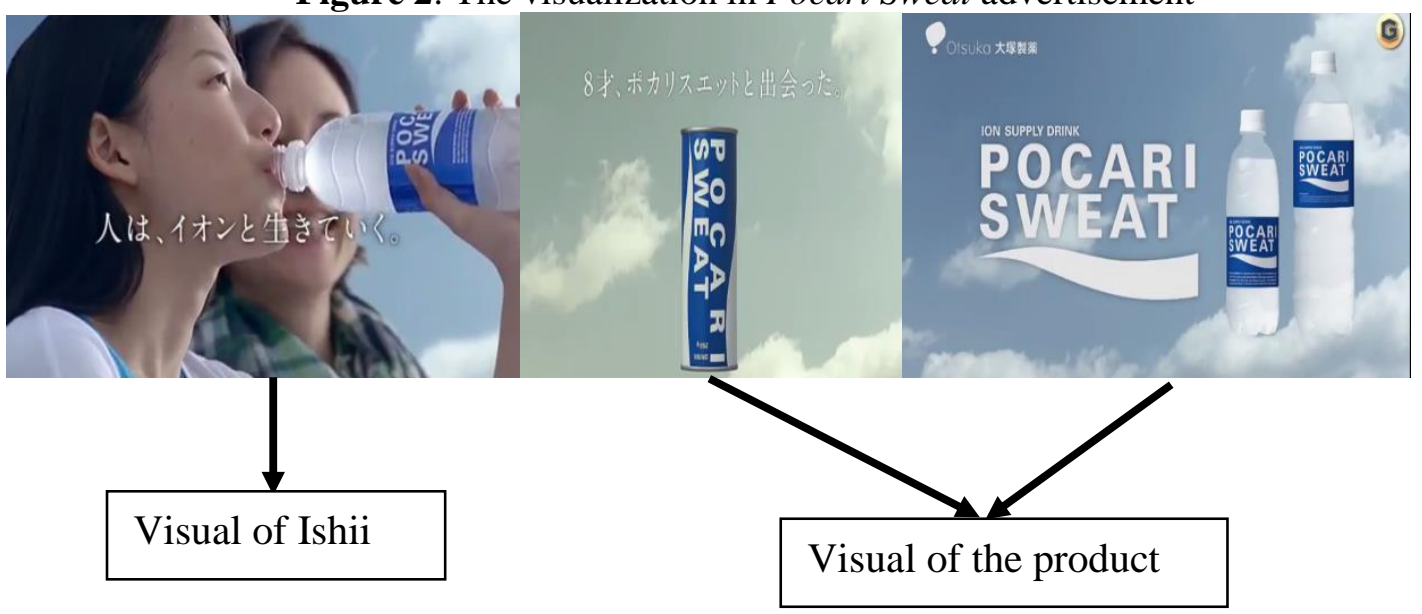

The dominant color of this advertisement is bright color identified from the background of the bright sky which signifies happiness when the product is consumed. Moreover, the combination between the visual of the actress and the visual of the product in this advertisement creates interpersonal meaning between the participants and the people. The interaction between the participants and the people is being recognized through the happy smile and eye contact which functions as the Demand. This situation shows that the participants are explaining the promoted product. The next process is to give the meaning on the good/product offered by the participants through the spoken verbal text explaining about the participants' experience and trust on the product since a long time ago.

Figure 3: The visualization of Ishii Anna in Pocari Sweat advertisement

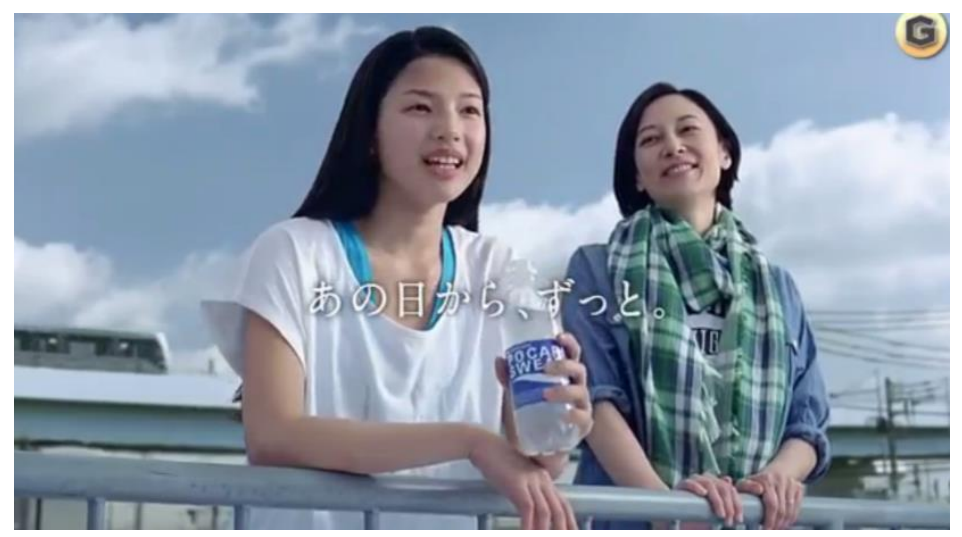

\subsection{Audio Analysis}

The background music of the activity in this advertisement is a famous pop song popularized by Gloria Gaynor entitled 'I love You Baby.' The music in this song signifies love, joviality and strong and healthy spirit of doing the activity. This is to show that the powerful quality of the product is best shown through the use of audio verbal element.

\subsection{Spatial Analysis}

Within the whole advertisement, the distance between one picture and the other picture has shown an integrated meaning. Each image has its own meaning yet supports the meaning of other images as well. The depiction of the spirited activity of the participants, the powerful quality of the product and the accessibility to get the product are shown by the distance of the pictures of the active participants, the making process of the advertisement and the depiction of the lead of the last image of the advertisement. 
The lead functions to give deep impression and meaning for the users/costumers. The lead identified in this advertisement is Locus of Attention (LoA) which realized in the following picture:

Figure 4: The lead in Pocari Sweat advertisement

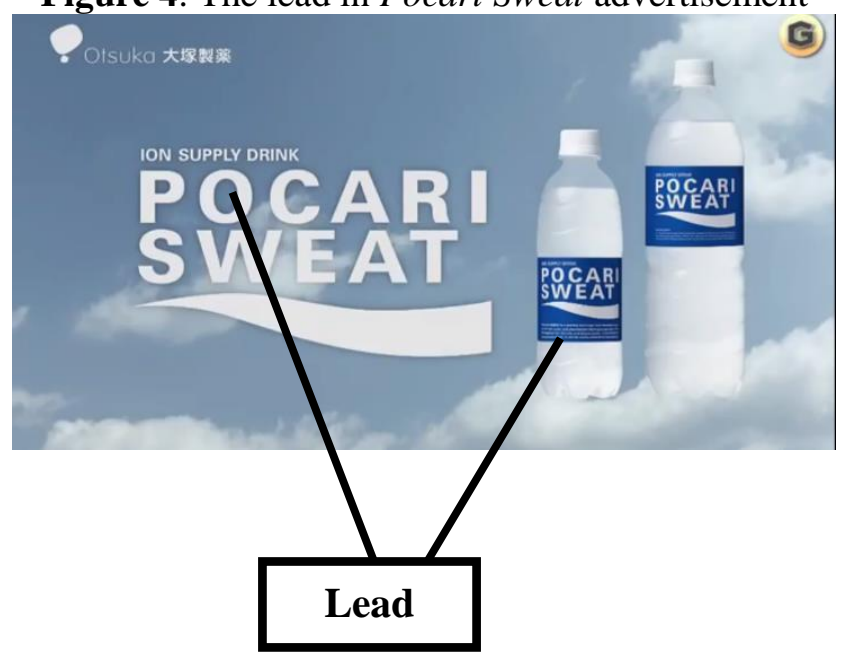

\subsection{Gesture Analysis}

Body movement and face expression are identified to be the gesture of the participants. Gesture in this advertisement is being realized from the participants' activities that done with full of spirit. It is well depicted from the process of the actress that at the same time performs as active and passive participants where the offering process done by the participants tells about the direct impact achieved from consuming offered product. Active and passive participation in this advertisement is shown by the happy smile expression and the active verbal utterance of ano hi karazutto Pocari Sweat followed by the written expression of the product emblem. The process is recognized in the following picture:

Figure 5: The gesture analysis of Pocari Sweat advertisement

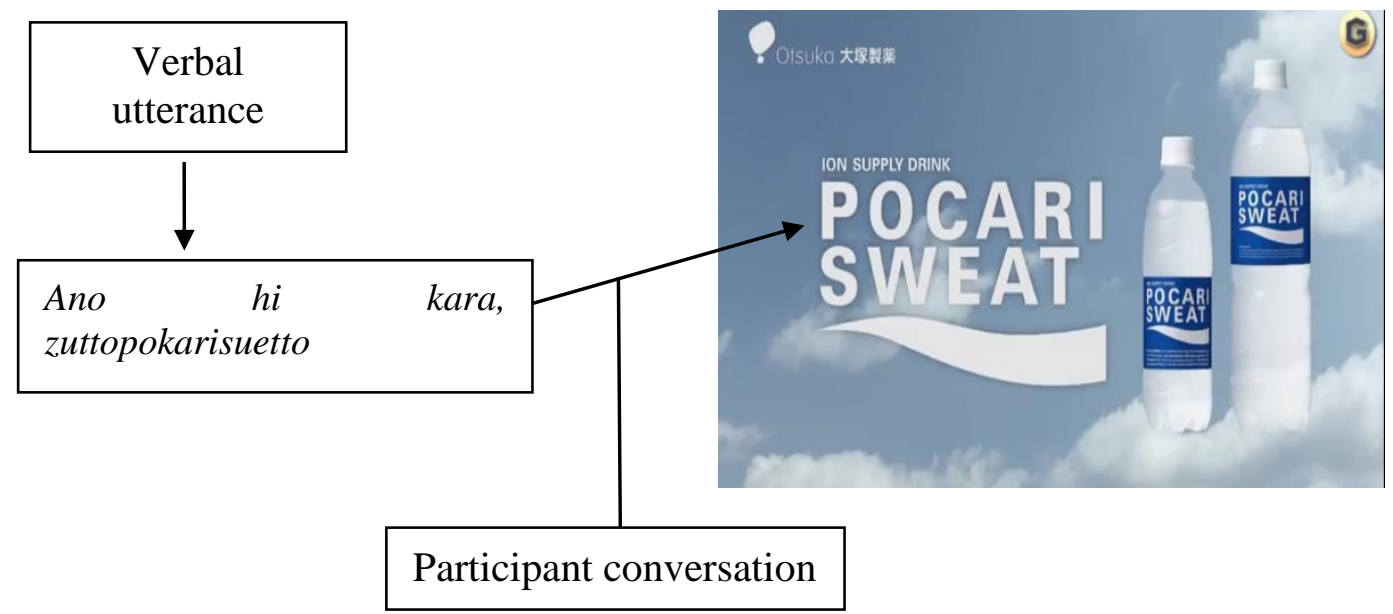

\section{Conclusion}

Multimodal analysis in Pocari Sweat advertisement entitled kizuna, oyakarako e dansu draws a conclusion that there is a multimodal semiotic system in the advertisement. Furthermore, every multimodal semiotic system is strongly related to one another in producing the meaning of the advertisement. The message enacted in the advertisement is comprehensive enough to be understood by everyone who watches it. 


\section{References}

Anstey, M. \& Geoff B. 2010. Helping teachers to explore multimodal texts. Curriculum and Leadership Journal, 8(16).

Halliday, M. A. K. 2004. An introduction to functional grammar. United States: Oxford University Press

Kotler, P. \& Gary A.2009. Prinsip-prinsip pemasaran, edisi 12 jilid 2. Jakarta: Erlangga.

Kress, G. \& Van Leeuwen, T. 2006. Reading images: The grammar of visual design. London: Routledge.

Matthiessen, C.M.I.M et.al. 2010. Key term in systemic functional linguistic. New York: Continuum International Publishing.

Sinar, T. S. 2012. Teori dan analisis wacana pendekatan linguistic sistemik fungsional. Medan: Mitra.

大塚製薬ポカリスエット $C M$ 石井杏奈「絆親から子へダンス」篇. Available at https://www.youtube.com/watch?v=AlHymwYqKLA. (Accessed 28 May 2018). 